derision, and even personal abuse. But despite indifferent health, she continues her work with determination.

The British Trust for Conservation Volunteers lists nearly thirty small, independent conservation groups in the county of Surrey alone. Not all run a continuous programme in the manner of the McAlmont Trust but, taken together, they probably represent the best hope for the
English countryside in its continuous battle against official neglect and ill-planned development.

CHRISTINE MARSH
l43 Peperharow Road
Godalming
Surrey GU7 $2 P W$
England, $U K$.

\title{
The Social Origins and Impact of Deforestation in Central America
}

The United Nations Research Institute for Social Development (UNRISD) has recently released a Discussion Paper entitled The Social Origins and Impact of Deforestation in Central America, by Peter Utting. The paper, based on research conducted during the late 1980s, describes the principal processes underlying deforestation in the region, the ways in which deforestation has affected the livelihood systems of different social groups, and individual and collective responses to those changes. The Author highlights the role played by government policies and land-tenure systems in deforestation processes, and examines the ways in which contemporary phenomena such as militarization, agrarian reform, and economic stabilization and adjustment, have affected deforestation.

The experience of forest protection initiatives in the region is also discussed, along with a brief assessment of some of their strengths and weaknesses from the point of view of contributing to environmental rehabilitation and social development. The Author concludes by outlining the content of a second phase of research, consisting of case-studies in Guatemala, Costa Rica, Nicaragua, and Honduras, which will shed further light on aspects associated with the social impact of deforestation and the effectiveness of different types of forest protection initiatives in promoting sustainable development.

The Discussion paper is part of the UNRISD research programme on the Social Dynamics of Deforestation in Developing Countries. The programme is concerned with the national and regional implications of deforestation for the livelihood and living conditions of poverty groups in rural and urban areas. Pertinent research is currently being carried out in Brazil, Central America, Nepal, and Tanzania, along with thematic studies on related issues.

The above research programme is being undertaken in coordination with UNRISD's ongoing work on Environment, Sustainable Development, and Social Change. Other programmes in this field include those of Sustainable Development through People's Participation in Resource Management; Women, Environment, and Social Change; Population Dynamics, Environmental Change, and Development; and the UNRISD Conference on Socioeconomic Dimensions of the Environmental Debate.

UNRISD was established nearly thirty years ago to promote research on the most pressing social issues of development. Multidisciplinary studies are carried out in collaboration with the Institute's extensive network of scholars and research institutes. Conferences are held in conjunction with research programmes, and there is active publication of research reports, discussion papers, and books. Inquiries about UNRISD research programmes and/or available publications should be addressed to: Reference Centre, United Nations Research Institute for Social Development, Palais des Nations, CH-1211 Geneva 10, Switzerland.

ADRIENNE CRUZ
UN Research Institute for Social Development
Palais des Nations
CH-1211 Geneva 10
Switzerland.

ADRIENNE CRUZ Palais des Nations Switzerland.

\section{Environment Protection Campaign in Southern India}

Environmental problems in India arise particularly from the ever-growing human and domestic-animal populations which are making increasing demands on natural resources. The result is the over-exploitation of the environment and its consequent degradation.

\section{Long-felt Need}

In India over $80 \%$ of the people live in villages. These villagers contribute a great deal to the degradation of the environment - by cutting the trees for firewood, by polluting the atmosphere with wastes, and by living in unhygienic conditions. Consequently we thought of tackling this problem at the grassroots level, aspiring to turn these people into agents of environmental protection.

The present-day environmental awareness programmes - using books, films, newspapers, magazines, electronic media, television, etc. - throughout the world have chiefly reached the wealthier and better-educated segments of the urban population. The vast majority of rural masses have been untouched by these campaigns. With a view to educating and training the rural people - especially women, agricultural labourers, and coolie workers - the Development Wing of SHEPHERD (a social extension and people's development unit) has spread the message of environmental protection and conservation from 1988 onwards.

\section{Awareness and Training}

As the village headman and the village development association are the most influential factors in any Indian village, we first gave a training programme on environmental protection to these people, and when once they had become convinced of our message, we were able to have wider influence and believe we have reached some 50,000 people in the last few years. We used a variety of teaching aids, including folk arts, puppetry, and street plays. The training is of three days' duration, and there is a follow-up every month to check that the trained people are following what they learnt during training sessions and to determine whether they take care to protect the trees and really do all they can to prevent pollution.

As a result of our training, villagers started forming Nature Clubs which act as the environment protecting and monitoring force in each village. The Nature Clubs raise seedlings in nurseries and distribute saplings to people. They also look after the cleanliness of the village. It is heartening to note that many of the villages which used to be barren when we began our work, can now boast of 